\title{
Teacher Readiness in Teaching and Learning History Process through i-Think Mind Maps
}

\author{
Mazlan Husin, Mohd Mahzan Awang², Anuar Ahmad³ \\ ${ }^{1}$ Faculty of Education, The National University of Malaysia \\ 2 Faculty of Education, The National University of Malaysia \\ 3 Faculty of Education, The National University of Malaysia
}

1 mazlanh@yahoo.com, 2mahzan@ukm.edu.com, 3anuarahmadukm@gmail.com

\begin{tabular}{ccc}
\hline Received & Accepted & Published \\
$03 / 04 / 2017$ & $21 / 06 / 2017$ & $31 / 07 / 2017$ \\
\hline & DOI & \\
& $10.26523 /$ yupa.v1i2.66 \\
\hline
\end{tabular}

\begin{abstract}
This research is aimed at investigating the readiness of History subject teachers in teaching and learning with the help of i-Think mind maps at secondary schools in the district of Setiu, Terengganu. The amount of sample chosen is 59 History teachers from secondary schools which consists of trained teachers without taking into account their specialization. As a whole, the research findings show that respondents have a high readiness level in implementing their teaching and learning process with the help of i-Think mind maps in secondary schools. The findings also show that there is a difference in teacher readiness between history teacher and non-history teacher and between those that went to courses and those who did not. Furthermore, there is a difference in the attitude, skill and usage level of i-Think mind maps in teachers that are experienced and those less experienced. However, research findings for experienced and less-experienced teachers showed that there are no significant differences in the level of knowledge on the concept of i-Think mind maps.
\end{abstract}

Keywords: i-Think mind maps, concept knowledge, teacher attitude, usage skill, usage level.

Abstrak Penelitian ini bertujuan untuk mengetahu kesiapan guru Sejarah dalam pengajaran dan pembelajaran dengan peta pikiran i-Think di sekolah menengah di Kabupaten Setiu, Terengganu.. Jumlah sampel yang dipilih adalah 59 guru sejarah dari sekolah menengah yang terdiri dari guru terlatih tanpa memperhatikan spesialisasi mereka. Secara keseluruhan, temuan penelitian menunjukkan bahwa responden memiliki tingkat kesiapan yang tinggi dalam menerapkan proses belajar mengajar dengan bantuan peta pikiran i-Think di sekolah menengah. Temuan juga menunjukkan bahwa ada perbedaan dalam kesiapan antara guru sejarah dan guru bukan sejarah dan mereka yang mengikuti kursus dan mereka yang tidak berpengalaman. Selanjutnya ada perbedaan dalam sikap, keterampilan dan tingkat penggunaan peta pikiran i-Think pada guru yang berpengalaman dan yang kurang berpengalaman. Namun, temuan penelitian untuk guru berpengalaman dan kurang berpengalaman menunjukkan bahwa tidak ada perbedaan signifikan dalam tingkat pengetahuan tentang konsep peta pikiran i-Think.

Kata Kunci: peta pikiran i-Think, pengetahuan konsep, sikap guru, keterampilan penggunaan, tingkat penggunaan. 


\section{INTRODUCTION}

The brilliance of a learner in the course of History much depends on the teaching and learning process applicable in the classroom. History subjects are often associated with the old teaching and learning process unchanging and boring method for most students (Nur Syazwani 2015). Changes for change are made to enhance the brilliance of the History course within the Malaysian education system. In harmony with the transformation experienced in History education, the Malaysian Ministry of Lessons has run several programs and updates to the History curriculum to support the transformation that once eradicated issues relating to education History is said to be a boring, difficult and insufficient subject in demand by most students. The introduction of the Standard Secondary School Curriculum and the Secondary School Standard Curriculum is an approach to improving students' understanding and achievement in schools, especially for history subjects. In harmony with KSSR and KSSM, the formation of high-level thinking skill carried out with correctly can resolve the issues that arise (Norakma 2015). Therefore, teachers need to design appropriate methods in the teaching and learning process that may help to improve the high-level thinking skill among learners.

The use of the i-Think map of thought in the teaching and learning process is a high-level thinking skill teaching technique introduced to encourage students to think and focus more on understanding the learned headline (Hyerle \& Yeager 2007). This is supported by Rohaida \& Zamri (2015) who advocate the implementation of i-Think programs in schools aiming to cultivate thinking skills toward producing innovative learners in the future. Each map of thought has a thought process that can be adapted to follow the header. The i-Think map of thought also helps learners actively stimulate thinking (Rosnidar et al, 2015). This method also indirectly develops the potential and produces creative and innovative human capital that is able to think at a very high level to reach the state educational philosophy (Sidek 2013).

History Education is one of the core subjects that must be taken by all students without thinking of the flow or type of school. Even the subjects of History are subjected to compulsory graduation in the ranking of Malaysian Certificate Lessons starting in 2012 which reflects how important these subjects are to the learners. Not only that, since the Standard School Curriculum was introduced in 2011, Historical subjects were introduced and taught in lower schools by 2014. It is aimed at fostering the interest and knowledge of History rather than lower school grades anymore. In order to achieve the objective of the state education curriculum, the KBAT program is implemented. According to Onosko \& Newmann (1994) defines High-Vision Thinking Skill as the potential use of mind to handle new challenges. The high-level thinking skill requires someone to understand, translate, analyze and manipulate the information (Yee Mei Heong, et al. Unknown). Changes in approaches in teaching and learning strategies need to 
be done to improve thinking skills among learners. One approach of the high-level thinking skill is to use the i-Think map of thought.

In the review of Rohaida \& Zamri (2015), the use of the i-Think map of thought as a way or a novel method that can stimulate high-minded students. The use of mind maps during the teaching and learning process can improve students' understanding and achievement compared to traditional or traditional methods. The use of this thinking map may be used as a new strategy for understanding the meaning of concepts contained in the text. This was supported by Khairuddin (2011) who used concept maps to help students understand the chronology of their learning. This achievement also equals with the study of Tengku Fairuse (2015) which states that KBAT is very memorable to be used in teaching and learning process.

Rosnidar et. al (2015) says students' achievement is very significant when students are involved directly in the process of producing i-Think thinking maps. Communication between teacher and pupil was also found to be more effective in his study which was also adapted to Hyerle's (2009) study that found that the map of thinking used was able to enhance the students' cognitive skills. Zohar (2014), supports the use of thought map to enhance the implementation of activities for KBAT. In addition, David (2011) and Laura (2011) in his study show that the use of i-Think thinking map can improve the level of student achievement and understanding as well as to improve the ability of students to use high-level thinking skills among students. According to Sidek and Rahim (2012), teachers' teaching practices through this thinking map have changed the behavior of students to more positive and diligent despite being practiced in no time.

Siti Zubaidah (2015) in his study expresses whoever can think, can be a creative person because creativity is not a function of intelligence. Creativity requires thinking techniques that can generate new ideas or produce something in new ways. Thinking skills are the basis for creating creative education among students. Thinking skills are applied to students through high-level questions, activities that promote thinking and problem solving as well as teaching methods that can drive towards improving thinking skills. Teacher expertise is needed in determining teaching and learning strategy. This means that the teacher can determine the approach, choose the method and apply the specific techniques according to the students' ability. The chosen strategies and techniques, as well as the potential to stimulate students to actively learn and also help to analyze concepts or ideas and strive to attract students and produce meaningful learning (Rohaida, 2015)

Norasmahani (2015), high-level thinking skill can help students to build self-confidence in expressing their views and being active in the learning process. The use of i-Think thinking map is a realistic and practical approach in the implementation of high-level thinking skill. The i-Think method can help them understand concepts and apply them in solving problems better. 
This coincides with the opinion of Nafsah (2014) which states that i-Think will produce students who are able to reason and think critically on every given issue making the meaning of learning more meaningful. Siti Noridah (2012) study shows problem solving activities, brainstorming and discussion questions can generate students' quality in teaching and learning process. In that regard, teachers need to help students to think creatively, solve problems and make decisions by teaching them cognitive strategies.

The emphasis on thinking skills in History at school is to allow brainstorming and pupils to be able to make decisions more rationally, reasonably and objectively (Rohaida, 2015). Starting 2015, all schools are encouraged to carry out 21st century learning aimed at enhancing and empowering thinking skills towards producing innovative students as contained in the Malaysia Education Blueprint 2013-2025 (KPM, 2013).

The high-level thinking skill program implemented at all schools in Malaysia is to foster students' interest in learning, helping the learning process in History subject in addition to enhancing academic achievement. In fact, the implementation of high-level thinking skill also aims to increase the confidence of students to ask the teacher and be prepared when asked by the current teacher in the room at the same time to incorporate students' thinking culture (Norakma, 2015). In the learning session, teachers often face different students in terms of their abilities. Teacher expertise is needed in determining teaching and learning strategy. This means that teachers can define approaches, choose methods and set specific techniques that suit the student's development and ability. The selected strategies and techniques, as well as the potential to stimulate students to learn actively and also to help analyze concepts or ideas and to empower students and to produce meaningful learning (PPK, 2002).

The study by Rosnidar (2015) found that there was an improvement in performance among students when involved directly in the use of i-Think thinking map. Students are able to understand the concept of i-Think thinking clearly and indirectly to attract students to learn and improve student achievement. However, the extent of the application of thinking skills among the History teachers during the teaching and learning process in the classroom. Fatah Hasan (1994) stated that in his study, teachers did not encourage students to think and teachers would prefer to give facts to memorize. This is evidenced in the study of Johnson G. and Price (2000) that students are less thoughtful and students are simply memorizing the concepts or facts given by the teacher or in textbooks only. Students are still not able to master their thinking skills and teachers need to take seriously to develop thinking skills in the teaching and learning process (Bernama, 2014). The focus of the teacher is more on providing information with the purpose of completing the syllabus and preparing students for the exam. According to Sharifah Nor (2012), there are some reasons why thinking skills are not emphasized as some teachers only think that students first master the facts and concepts of a subject before students can be 
encouraged to think. Maimunah (2004) said changes from using conventional methods to the teaching and learning method require a high commitment or a big challenge.

Additionally, the attitude of teachers who usually use note-line or traditional note notes, at the end of the lesson as strengthening of the teaching is likely to make the students feel bored and forget about the content of the lesson. Wong \& Amir (2012) has identified in his study because students feel bored with long notes and students learn only a fraction of the facts they learn. Additionally, students are also not interested in revising their notes with long notes. Success and excellence in a subject will not be a reality if the teaching of the teacher is still using the traditional method and does not take into account aspects of thinking skills (Zamri, 2012). In this regard, researchers are keen to see the extent of the knowledge and readiness of high school history teachers on the use of i-Think thinking map in the teaching and learning process in the classroom and researchers also want to see the extent of their use.

\section{METHOD}

This research is a correlational quantitative research by identifying the readiness of the History teachers in the national secondary schools in Setiu District, Terengganu in applying the use of i-Think thinking map among students in order to achieve the goals and objectives of History teaching. And identify whether there is a difference between the level of readiness of teachers of history and some factors of teacher background such as specialization, teaching experience and courses attended.

The hypotheses used in this study that attempt to be proved as follows:

Ho1: There is no mean difference between the level of understanding of the concept of i-Think History teachers with specialization

Ho2: There is no mean difference between the level of readiness of teachers in terms of the attitude of the teachers of History and the areas of specialization.

Ho3: There is no significant difference between the skills of using i-Think History teachers with specialization fields.

Ho4: There is no difference in the level of use of i-Think History teachers with specialization. The mean difference of readiness with teaching experience

Ho5: There is no significant difference between the level of understanding of the concept of iThink History teachers with experienced and less experienced teachers.

Ho6: There is no mean difference between the level of readiness of teachers in terms of attitude of the history teachers with experienced and less experienced teachers.

Ho7: There is little difference between the use of i-Think History teachers with experienced and less experienced teachers. 
Ho8: There is no mean difference between the level of use of i-Think History teachers with experienced and less experienced teachers. The mean difference between the level of readiness and the course

Ho9: There is no mean difference between the level of understanding of the concepts of iThink History teachers with who ever attended the course and had never been present.

Ho10: There is no mean difference between the level of readiness of the teacher in terms of the attitude of the History teachers with who ever attended the course and had never been present.

Ho11: There is no mean difference between the use of i-Think History teachers with the everpresent and unprecedented courses.

Ho12: There is no mean difference between the level of use of i-Think History teachers and teachers who have attended the course and have never been present.

The sample of the study was composed of History teachers in government secondary schools that taught KBSM History in the State of Terengganu. The study only relies on a sample to represent the population. This is due to the cost limit, mas and energy. The teachers selected in this study are composed of all trained teachers who teach KBSM History subjects from History specialization and not specialization in 14 national secondary schools in the district of Setiu, Terengganu.

This study was conducted by survey and information gathering from the sample was conducted using questionnaire. This study focuses on the use of i-Think thinking map by historical teachers in the process of teaching and learning in the classroom. i-Think is an approach used to promote high-level thinking skills among students. Thinking map i-Think has eight thought maps, circle maps, bubble map, double bubble map, tree map, mapping map, flow chart, multi-flow map and bridge map. The researcher uses independent variables to see the relationship with predetermined dependent variables, which is the level of teacher readiness to the use of i-Think thinking map. The independent variables that have been selected are teacher specialization, teaching experience and i-Think course attendance. This independent variable will be related to the dependent variable ie the level of readiness of the teacher towards the use of i-Think thinking map.

The data collection process for this study is through a set of questionnaires that have been developed by the researcher on the basis of literary reading and teaching experience of their own researcher and discussion with the supervisor. This questionnaire was distributed to research respondents by researchers. The questionnaire was constructed that respondents answered according to the likert scale which was ranked into four categories. The questionnaire was composed of 5 parts, namely Part A, B, C, D and E. The focus of the items in section A was the background of the respondents. Information includes gender, age, race, specialization, 
history teaching experience and have attended i-Think related courses or have never attended. Part B contains items on the concept of i-Think concept, part C contains items on teacher readiness in terms of attitudes, part $\mathrm{D}$ contains items on i-Think use skills and part $\mathrm{E}$ are items about the level of i-Think usage among teachers.

Two stages of statistical analysis were carried out, namely descriptive statistics and inferential statistics. For descriptive statistics, mean analysis and standard deviation were done based on the three-level scale of high, medium and low (Abdull Sukor Shaari et al, 2008) as can be seen in Table 1. While the inference statistic is done using the t-test to see level of readiness based on specialization, teaching experience and course attendance.

Table 1. Score Interpretation

\begin{tabular}{cc}
\hline Julat Min & Tahap \\
\hline $1.00-2.00$ & Low \\
$2.01-3.00$ & Medium \\
$3.01-4.00$ & High \\
\hline
\end{tabular}

\section{RESULT AND DISCUSSION}

\section{Overall Readiness of teachers}

The analysis of the collected data from the questionnaire for readiness of teachers teaching the subjects of History is as follows:

Table 2. Score of teacher readiness as a whole

\begin{tabular}{lccc}
\hline Aspek kajian & Min & S.P & Tahap \\
Knowledge of i-Think concept & 3.2650 & .40066 & High \\
Attitude & 3.1051 & .31917 & High \\
Usage skills & 2.8712 & .23566 & Medium \\
Usage level & 2.9915 & .43710 & Medium \\
Overall score & 3.0582 & .34825 & High \\
\hline
\end{tabular}

Based on Table 2 above, the overall mean readiness score on the use of the i-Think thinking map to the students is 3.0582 and the standard deviation is 0.34825 . This mean score indicates that respondents who teach the students of History in high school in the district of Setiu have a high level of readiness to implement the use of i-Think thinking map in the process of teaching and learning History. In this case, respondents' readiness covers all aspects of the concept of i-Think concept, attitude, usage skill, and level of use. The highest readiness aspect is the concept of i-Think concept (min 3.265) followed by other aspects, namely attitude (min 3.1051), usage level ( $\min 2.9915$ ) and followed by usage skill (min 2.8712). 


\section{Readiness from Knowledge Aspects of the i-Think Concept}

Table 3 shows the level of readiness of respondents from the conceptual aspects of $i-$ Think concept. Based on Table 3, the level of readiness of respondents about this aspect as a whole is at a high level of min 3.265. It can be concluded that overall a high level of knowledge about the general concepts of i-Think thinking maps should be used in teaching and learning in the classroom.

Table 3. Readiness table from aspect of i-Think concept knowledge

\begin{tabular}{|c|c|c|c|c|}
\hline & Review Aspect / Item & Min & $\mathrm{SP}$ & Stage \\
\hline 1 & i-Think means innovative thinking & 3.34 & .477 & High \\
\hline 2 & $\begin{array}{l}\text { The use of i-Think can enhance and } \\
\text { empower students' thinking skills }\end{array}$ & 3.36 & .550 & High \\
\hline 3 & $\begin{array}{l}\text { The use of i-Think can produce creative, } \\
\text { critical and innovative thinking. }\end{array}$ & 3.34 & .545 & High \\
\hline 4 & i-Think has eight thought maps & 3.37 & .554 & High \\
\hline 5 & $\begin{array}{l}\text { The use of i-Think can give birth to an } \\
\text { active student in the classroom }\end{array}$ & 3.24 & .567 & High \\
\hline 6 & $\begin{array}{l}\text { The use of i-Think can make the learning } \\
\text { situation fun }\end{array}$ & 3.29 & .559 & High \\
\hline 7 & $\begin{array}{l}\text { The use of i-Think can improve student } \\
\text { academic performance }\end{array}$ & 3.15 & .551 & High \\
\hline 8 & $\begin{array}{l}\text { The use of i-Think makes students more } \\
\text { focused while studying }\end{array}$ & 3.20 & .581 & High \\
\hline 9 & $\begin{array}{l}\text { The use of i-Think can increase student } \\
\text { confidence }\end{array}$ & 3.17 & .673 & High \\
\hline 10 & $\begin{array}{l}\text { The use of i-Think can deepen the } \\
\text { teacher's relationship with the students }\end{array}$ & 3.25 & .544 & High \\
\hline \multirow[t]{2}{*}{11} & $\begin{array}{l}\text { The use of i-Think can produce students } \\
\text { with high levels of reasoning }\end{array}$ & 3.20 & .550 & High \\
\hline & Overall Score & 3.265 & 0.559182 & High \\
\hline
\end{tabular}

\section{Readiness from Attitude Aspects}

Based on Table 4, the overall mean of respondents' attitude towards the use of i-Think thinking map to students is 3.106. This shows that respondents have a high attitude in applying the use of i-Think thinking map in the process of teaching and learning history. From the overall attitude item in Table 4, the highest mean score is in item 8, "I feel that students need to be exposed to a new approach in the PdP process especially regarding the use of i-Think" with (mean 3.38). The smallest point is in item 7, "I'm very keen to do i-Think study / reading as a teaching preparation" (mean 2.90). Respondents have a modest positive attitude in the effort to make a study or reading related to i-think as preparation before the process of teaching and learning is conducted. 
Table 4. Readiness schedule from attitude aspect

\begin{tabular}{|c|c|c|c|c|}
\hline & Review Aspect / Item & Min & SP & Stage \\
\hline 1 & $\begin{array}{l}\text { I am always ready to accept new ideas } \\
\text { related to teaching using i-Think }\end{array}$ & 3.31 & .500 & High \\
\hline 2 & $\begin{array}{l}\text { I have to think out of the box in the i- } \\
\text { Think program }\end{array}$ & 3.27 & .520 & High \\
\hline 3 & $\begin{array}{l}\text { I am willing to take some risks that may } \\
\text { occur in the use of i-Think }\end{array}$ & 3.03 & .490 & High \\
\hline 4 & $\begin{array}{l}\text { I am willing to accept the error regarding } \\
\text { the use of the i-Think map }\end{array}$ & 2.98 & .473 & Medium \\
\hline 5 & $\begin{array}{l}\text { I did not allow my experience and } \\
\text { practice to influence my thinking on the } \\
\text { use of the i-Think map }\end{array}$ & 2.92 & .535 & Medium \\
\hline 6 & $\begin{array}{l}\text { I collect various resources or materials } \\
\text { related to i-Think for teaching purposes }\end{array}$ & 3.00 & .525 & High \\
\hline 7 & $\begin{array}{l}\text { I am very interested in making i-Think } \\
\text { related study / readings as teaching } \\
\text { preparations }\end{array}$ & 2.90 & .480 & Medium \\
\hline 8 & $\begin{array}{l}\text { I feel that students need to be exposed to } \\
\text { a new approach in the PdP process } \\
\text { especially regarding the use of i-Think }\end{array}$ & 3.34 & .512 & High \\
\hline 9 & $\begin{array}{l}\text { I believe that History teaching becomes } \\
\text { more effective with the use of i-Think }\end{array}$ & 3.24 & .597 & High \\
\hline \multirow[t]{2}{*}{10} & $\begin{array}{l}\text { I'm always ready to use } \mathrm{i} \text {-Think in the } \\
\text { teaching and learning process. }\end{array}$ & 3.07 & .553 & High \\
\hline & Overall Score & 3.106 & 0.5185 & High \\
\hline
\end{tabular}

\section{Readiness from Usage Skills Aspect}

Referring to Table 5, respondents' readiness in terms of the skills of using i-Think thinking map overall is at a moderate level, with mean 2.87. This means that respondents have a modest skill to use eight i-Think thinking maps to the students during the teaching and learning process. Although the respondents have moderate skills, if viewed at the mean sequence of each item, the highest mean and showed a fairly good respondent's knowledge is in item 4 of the "tree map" (mean 3.22). The smallest mean score is on the item, "multi-flow map" (min 1.97). This means that the respondents are less skilled in using the types of i-Think thinking map in the teaching and learning process in the classroom.

Table 5. Readiness table on aspects of utilization skills

\begin{tabular}{|c|c|c|c|c|}
\hline & Review Aspect / Item & Min & SP & Stage \\
\hline 1 & $\begin{array}{l}\text { Map circle is used to define objects or } \\
\text { ideas }\end{array}$ & 3.17 & .497 & High \\
\hline 2 & $\begin{array}{l}\text { Map bubbles are only used to describe the } \\
\text { nature of a thing }\end{array}$ & 3.05 & .655 & High \\
\hline 3 & $\begin{array}{l}\text { Double foam maps are not suitable for } \\
\text { explaining the similarities and differences } \\
\text { of objects }\end{array}$ & 2.97 & .694 & Medium \\
\hline 4 & Tree map is used to classify something & 3.22 & .527 & High \\
\hline
\end{tabular}


5 The rugged map to describe the

.427

High

component or part that forms the physical

object

6 Flow map is not suitable for explaining

.749

Medium

reasons and effects

$7 \quad$ Multi-map maps are used to describe the

1.97

.718

Low

sequence of events and their stage of

development

8 To find an affinity or an analogy, the

.485

High

bridge map is appropriate

9 I believe I will be able to use the i-Think map if I always use it

.638

High

10 Map i-Think is actually the same as mind map

.779

Medium

Overall Score

$2.87 \quad 0.6169$

Medium

\section{Teacher's Readiness from Usage Level Aspect}

Based on Table 6, the level of readiness of the respondents as a whole in terms of using the i-Think thinking map as a whole is at a moderate level of min 2.992 . They can be said to rarely use i-Think thinking map in the process of teaching and learning History subjects in the classroom. The highest score is for item 4 "I am engaging with students in learning activities using i-Think" (mean 3.17). While for item 9 "I always use i-Think for teaching and learning process shows the lowest mean score (min 2.75).

Table 6. Readiness table from aspect of use

\begin{tabular}{lllcc}
\hline & Review Aspect / Item & Min & SP & Stage \\
\hline 1 & $\begin{array}{l}\text { I plan ahead of use the i-Think map to the } \\
\text { topics to be taught }\end{array}$ & .471 & High \\
2 & $\begin{array}{l}\text { I recorded the use of the i-Think map as } \\
\text { one of the activities in the Daily Lesson } \\
\text { Plan }\end{array}$ & 3.02 & .572 & High \\
$3 \quad \begin{array}{l}\text { I guide students using the appropriate i- } \\
\text { Think map }\end{array}$ & 3.15 & .485 & High \\
$4 \quad \begin{array}{l}\text { I am engaging with students in activities } \\
\text { pembelajaran menggunakan i-Think }\end{array}$ & 3.17 & .461 & High \\
$5 \quad \begin{array}{l}\text { I always emphasize the students about } \\
\text { the goodness of using i-Think }\end{array}$ & 3.03 & .586 & High \\
$6 \quad \begin{array}{l}\text { I always encourage students to use i- } \\
\text { Think in the learning process } \\
7\end{array}$ & 2.97 & .642 & Medium \\
$\begin{array}{l}\text { I always explain to students about using } \\
\text { the appropriate i-Think map }\end{array}$ & 2.98 & .601 & Medium \\
$\begin{array}{l}\text { I always fixes if students use Map i-Think } \\
\text { that are not compatible with the topic }\end{array}$ & 3.02 & .629 & High \\
$9 \quad \begin{array}{l}\text { I always use the i-Think teaching and } \\
\text { learning process } \\
\text { At the end of the teaching and learning } \\
\text { process, I summarized the good use of } \\
\text { Map i-Think in the learning process } \\
\text { Overall Score }\end{array}$ & 2.75 & .604 & Medium \\
\hline
\end{tabular}


Table 7 shows the t-test of the mean level of readiness of concept knowledge readiness (Ho1), attitude (Ho2), skill (Ho3) and use (Ho4) between history historians and non-specialists. Based on table 7, all four hypotheses are rejected. This means that there is a significant difference in the readiness of knowledge between historians who are historians and nonspecialists. The mean score of the four levels of readiness for respondents who historically is higher than the mean score of respondents who are not specialists in history. This suggests that respondents who are historically have higher levels of readiness in all four aspects than nonspecialization.

Table 7. Schedule the mean difference level of readiness with specialization

\begin{tabular}{llccccc}
\hline $\begin{array}{l}\text { Construct } \\
\text { readiness }\end{array}$ & Specializations & $\mathrm{N}$ & Min & S.P & $\mathrm{t}$ & Sig \\
\hline $\begin{array}{l}\text { Conceptual } \\
\text { knowledge } \\
\text { (Ho1) }\end{array}$ & History Education & 32 & 3.2694 & .44581 & - & .000 \\
$\begin{array}{l}\text { Attitude } \\
\text { (Ho2) }\end{array}$ & History Education & 27 & 3.2614 & .34799 & 21.709 & \\
& Non History Education & 32 & 3.1063 & .36095 & - & .000 \\
Skills (Ho3) & History Education & 32 & 3.1037 & .26816 & 21.219 & \\
& Non History Education & 27 & 2.8844 & .23706 & - & .000 \\
& & & & .23751 & 19.117 & \\
Usage (Ho4) & History Education & 32 & 3.0844 & .37684 & - & .000 \\
& Non History Education & 27 & 2.8815 & .48361 & 15.944 & \\
& & & & & & \\
\hline
\end{tabular}

Table 8 shows that there is no difference in the level of knowledge of the concept of $\mathrm{i}$ Think of historical teachers between experienced teaching history of less than 10 years and over 10 years (sig 0.188) With other words the level of readiness of the knowledge of the concept of i-Think respondents who teach History is the same without taking into account the teaching experience. Hence, the hypothesis (Ho5) is a failure to reject. While for Ho6, Ho7 and Ho8 on the readiness of attitude, skills and usage suggest that there is a difference in level of readiness in terms of attitudes, skills and the use of i-Think thinking map among experienced teachers teaching history less than 10 years and more than 10 years in applying using i-Think thinking map to students. In other words, the null hypotheses of Ho6, Ho7 and Ho8 are rejected. There are a variety of mean scores of attitude readiness, skills and use of i-Think thinking maps for experienced respondents teaching history with the inexperienced teaching of History.

In terms of attitude readiness, experienced teachers teaching less than 10 years showed higher mean score ( $\min 3.1609$ ) than experienced teachers teaching more than 10 years. This means that experienced teachers teach less than 10 years to be more positive towards the use of i-Think thinking maps than experienced teachers teaching more than 10 years. From the aspect of skills, experienced teachers teaching more than 10 years showed a higher mean score (min 2.8892) as compared to the mean score of experienced teachers teaching less than 10 years 
(mean 2.7376). In terms of level of use, experienced teachers teaching 10 years and above showed a higher mean score (min 3.0946) than experienced teachers teaching less than 10 years (mean 2.6930). This shows that experienced teachers teaching 10 years and above have the skills of using i-Think thinking map higher and using i-Think thinking map more often than experienced teachers teaching less than 10 years. However, the usage skills and the i-Think usage level are still at a moderate level.

Table 8. The table is the difference between the mean level of readiness and the teaching experience

\begin{tabular}{llccccc}
\hline $\begin{array}{l}\text { Construct } \\
\text { readiness }\end{array}$ & Specializations & $\mathrm{N}$ & $\mathrm{Min}$ & $\mathrm{S} . \mathrm{P}$ & $\mathrm{t}$ & $\mathrm{Sig}$ \\
\hline Conceptual & Under 10 years & 22 & 3.1523 & .40121 & 1.332 & .188 \\
knowledge (Ho5) & 10 years above & 37 & 3.2703 & .41188 & & \\
Attitude (Ho6) & Under 10 years & 22 & 3.1609 & .32372 & 2.720 & .009 \\
& 10 years above & 37 & 3.1081 & .32777 & & \\
Skills (Ho7) & Under 10 years & 22 & 2.7376 & .25313 & 5.099 & .000 \\
& 10 years above & 37 & 2.8892 & .21958 & & \\
Usage (Ho8) & Under 10 years & 22 & 2.6930 & .49268 & 4.045 & .000 \\
& 10 years above & 37 & 3.0946 & .37929 & & \\
\hline
\end{tabular}

Table 9 shows the t-test of the mean of the level of readiness of concept knowledge (Ho9), attitude (Ho10), skill (Ho11) and the use of i-Think (Ho12) Based on table 8, all four hypotheses are rejected. This means there is a significant difference in readiness between historians who have never attended the course. The mean score of all four levels of readiness for respondents who attended the course was higher than the mean score of respondents who had never attended the course. This shows that respondents who attended the course had higher levels of readiness in all four aspects than those who had never attended the course.

Table 9. The table is the mean difference of readiness with the attendance of the course

\begin{tabular}{llccccc}
\hline $\begin{array}{l}\text { Construct } \\
\text { readiness }\end{array}$ & Course attendance & $\mathrm{N}$ & Min & S.P & $\mathrm{t}$ & Sig \\
\hline $\begin{array}{l}\text { Conceptual } \\
\text { knowledge (Ho9) }\end{array}$ & Ever Present & 43 & 3.3108 & .38987 & - & .000 \\
& Never Present & 16 & 3.1420 & .41589 & 23.371 & \\
Attitude (Ho610) & Ever Present & 43 & 3.1279 & .30886 & - & .000 \\
& Never Present & 16 & 3.0438 & .34827 & 24.274 & \\
Skills (Ho11) & Ever Present & 43 & 2.8884 & .23625 & - & .000 \\
& Never Present & 16 & 2.8250 & .23523 & 23.140 & \\
& & & & & & \\
Usage (Ho12) & Ever Present & 43 & 3.0349 & .43855 & - & .000 \\
& Never Present & 16 & 2.8750 & .42505 & 19.558 & \\
\hline
\end{tabular}


The findings show that the level of preparedness of the History teachers in some aspects which includes the conceptual knowledge, attitudes, skills and the level of use of i-Think thinking map as a whole is at a high level. This high level of readiness is important in ensuring the effectiveness of the teaching and learning process of the History subject to the students. Aspects of specialization of teachers and courses attended are important aspects that can affect the level of readiness of Historian teachers. Aspects of teacher teaching experience only affect readiness in attitude, usage skill and level of use only. While in terms of conceptual knowledge is the same between experienced teachers with less experience. Therefore, it is recommended that the parties extend the local reading material to i-Think thinking map and the teaching modules with i-Think thinking map as a guide. In addition, historical teachers who are proficient in using this map can guide other less-skilled teachers. The university and the Teacher Education Institute can improve the understanding of trainee teachers on pedagogical knowledge with iThink thinking map. Replication of recommended courses is more practical.

Overall the level of readiness of the History teachers towards the use of i-Think thinking map is at an already high level. This high readiness shows that teachers demonstrate their commitment in order to intensify their use more effectively and to produce high-level thinking students. The findings of the study show that the aspect of the readiness of usage skills and the level of use of the i-Think thinking map among the History teachers as a whole is at a moderate level. The results of the t-test analysis to see the difference in mean levels of readiness of teachers of History between specializations and among previously and never-before-did-have courses show Historical teachers with specialization History have a better level of readiness than non-specialized teachers. Next, teachers who attended the course were more than teachers who had never attended the course. It is also suggested that priorities should be given to teachers who are specialized in History to teach History subjects and i-Think related courses should be extended to teachers teaching History subjects. The t-test also shows that there is a difference in the level of readiness of the Historian's teacher in terms of attitudes, usage skills and the level of use of i-Think thinking map based on teaching experience. However, for the level of readiness in terms of conceptual knowledge indicates the level of readiness of the less experienced teachers with experienced teachers.

\section{CONCLUSION}

The findings show that the readiness of the respondents in all aspects of the study which covers aspects of conceptual knowledge, attitudes, usage skills and usage level on i-Think thinking map in the process of teaching and learning of History subjects are already at high level. This finding means that the History teachers especially agree and are willing to embrace the teaching and learning process using i-Think thinking map. Furthermore, given the 
differences in the mean level of readiness of respondents in all four aspects of readiness between specializations, there is a difference between the History and non-History. Respondents who are historically have higher readiness in all four aspects of the study than non-History. The findings also show that the level of readiness in terms of attitudes, usage skills and the level of use of thought maps is the same among experienced skeletons with experienced teachers. Only teachers with less than 10 years of experience have higher i-Think concept knowledge than those with over 10 years of experience. Finally, the findings also found that respondents who attended the I-Think thinking map course had a better readiness than those who had never attended.

The aspects of teacher readiness that have been discussed are among the fundamental aspects that are essential to the Master's teachers in improving their professionalism, especially in History education in schools in this 21st Century. Without an understanding and effective application in these aspects, the implementation of the teaching and learning process using the i-Think thinking map in History is difficult to be implemented, so efforts to produce highthinking students will not be a reality.

\section{REFERENCES}

Bernama. 2014. 36,304 Dapat Semua A Dalam UPSR 2014, Pencapaian Keseluruhan Menurun Diperoleh pada $16 \quad$ Oktober $2016 \quad$ daripada http://www.bernama.com/bernama/v7/bm/ge/newsgeneral.php?id=1088408.

Hyerle, D. 2009. Thinking Maps: Visual Tools For Activating Habits of Mind. US: Thinking Maps Inc.

Ishak, I. Z. 2002. Kualiti Pensyarah Politeknik Lepasan Sarjana Pendidikan Kolej Universiti Teknologi Tun Hussein Onn(Kuittho). Kolej Universiti Teknologi Tun Hussein Onn:Tesis Ijazah Sarjana.

Kementerian Pendidikan Malaysia. 2013. Pelan Pembangunan Pendidikan Malaysia 2013-2025. Putrajaya: Bahagian Pendidikan Guru.

Khairudin Ahmad. 2011. Keberkesanan kaedah peta konsep terhadap pencapaian, sikap, dan kemahiran memahami kronologi dalam kalangan pelajar tingkatan empat. Tesis Sarjana Pendidikan. Fakulti Pendidikan, Universiti Kebangsaan Malaysia.

Laura A. W. 2011. The effect of thinking maps on students' higher order thinking skills. US:California State University \& Northridge University.

Maimunah Osman 2004. Kemahiran berfikir. Kuala Lumpur: Institut Tadbiran Awam Negara (INTAN).

Muhamad Sidek Said \& Ahamad Rahim. 2012. Inovasi pengajaran dan pembelajaran melalui program i-Think. IPGM International convention in teacher learning \& development, Pearl International Hotel, Kuala Lumpur, 19-21 Nov 2012. 
Muhamad Sidek Said. 2013. Aplikasi menggunakan "thinking map" dalam program praktikum KPLD Di Tadika Yayasan Islam Terengganu, Seberang Takir, Kuala Terengganu. Seminar Kajian Tindakan Peringkat Kebangsaan, 23-25 April, 2013.

Nafsah Mohd Shah. 2014. Integrasi VLE-Frog dan I-Think serta penggunaannya sebagai satu transformasi dalam pengajaran dan pembelajaran Pendidikan Islam. Projek Sarjana Pendidikan, UKM.

Norakma Mohd Daud, Abdul Razak Ahmad \& Noria Munirah Yakub. 2015. Pembelajaran berteraskan kemahiran berfikir aras tinggi (KBAT) di dalam pengajaran dan pembelajarn mata pelajaran Sejarah. Proceeding: 7th International Seminar on Regional Education, November 5-7, 2015. hlm 352-360.

Norasmahani Nor, Nur Sofiah suhaimi, Nur Syamira Abdul Wahab, Mohd Khusshairi che Ismail, Mohd Aderi Noh \& Khadijah Abdul Razak. 2015. Pelaksanaan KBAT dalam pengajaran dan pembelajaran Pendidikan Islam sekolah menengah: Satu tinjauan di Putrajaya. Proceeding: 7th International Seminar on Regional Education, November 5-7, 2015. hlm 361-375

Nur Syazwani Abdul Talib, Mohd Mahzan Awang \& Abdul Razaq Ahmad. 2015. Penggunaan pelbagai sumber dalam pendidikan Sejarah dan hubungannya dengan minat belajar Sejarah. National Research Seminar 2015, hlm. 435-444.

Onosko, J. J, \& Newmann, F. M. 1994. Creating More Thoughtful Learning Environment.in Mangieri, J. \& Blocks, C. C. (Eds.). Creating Powerful Thinking In Teachers And Students: Diverse Perspectives. Forth Worth: Harcourt Brace College Publishers

Pusat Perkembangan Kurikulum 2002. Kemahiran berfikir dalam pengajaran dan pembelajaran. Putrajaya: Kementerian Pelajaran Malaysia

Rohaida Yusop \& Zamri Mahmood. 2015. Keberkesanan peta pemikiran (i-Think) dalam meningkatkan pencapaian penulisan Bahasa Melayu murid tahun 6. Jurnal Pendidikan Bahasa Melayu 2 (5): 31-37.

Rosnidar Mansor, Haeidatul Nashrah Hassan, Norazilawati Abdullah \& Nik Azmah Nik Yusof. 2015. Keberkesanan penggunaan i-Think terhadap pencapaian dan minat murid dalam tajuk sifat bahan, Sains tahun 4. Junal Pendidikan Sains \& Matematik Malaysia 2(5): 98116.

Sharifah Nor Puteh. 2012. Keperihatinan guru Bahasa Melayu dalam melaksanakn kemahiran berfikir secara kritis dan kreatif. Jurnal Pendidikan Bahasa Melayu, 2 (2): 19-31.

Siti Noridah Ali. 2012. Malaysian Polytechnique Lectures teaching practise with ICT utilization to promote HOTS. Thesis Doctor of Philosophy. Ohio University USA.

Siti Zubaidah Che Mohd Noor \& Abdul Razak Ahmad. 2015. Kreativiti guru dalam meningkatkan kefahaman dan penghayatan Sejarah. Proceeding: 7th International Seminar on Regional Education, November 5-7, 2015. hlm 457-468.

Suriana Ismail. 2012. Kesediaan guru terhadap pelaksanaan mata pelajaran reka bentuk dan teknologi (RBT) sekolah rendah di Malaysia. Laporan Projek Ijazah Sarjana, Fakulti Pendidikan Teknik dan Vokasional, Universiti Tun Hussien Onn.

Tengku Fairuse Tengku Hassan. 2015. Tahap kemahiran guru bahasa melayu dalam menerapkan amalan kemahiran berfikir aras tinggi (KBAT) semasa pengajaran dan pembelajaran di bilik darjah. Kertas Projek Sarjana Penddikan. Fakulti Pendidikan, Universiti Kebangsaan Malaysia. 
Wong Leng Sim \& Amir Hamzah Sharaai. 2012. Penggunaan Peta Minda Untuk Meningkatkan Daya Mengingat dan Minat Mengulang Kaji bagi Pelajar Tahun 4 dalam Topik Pembiak Tumbuhan. Selangor : Universiti Putra Malaysia.

Yee Mei Heong,Jailani Md Yunos, Suzanna Ibrahim, Widad Othman dan Tee Tze Kiong. Unkown. Pola Kemahiran Berfikir Aras Tinggi Marzano Berdasarkan Dimensi Menggunakan Pengetahuan Bermakna.

Zahara Aziz \& Nik Azleena Nik Ismail. 2007. Kajian tinjauan kesediaan guru-guru Sejarah menerapkan kemahiran pemikiran sejarah kepada para pelajar. Jurnal Pendidikan 32 (2007): 119-137.

Zohar, A. 2004. Elements of teachers' pedagogical knowledge regarding instruction of higher order thinking. Journal of Science Teacher Education, 15(4): 293-312. 